\title{
Psychological Needs as the Predictor of Teachers' Perceived Stress Levels
}

\author{
Ahmet Avci ${ }^{1}$, Hasan Bozgeyikli ${ }^{2}$, Sahin Kesici ${ }^{3}$ \\ ${ }^{1}$ Faculty of Education, Fatih Sultan Mehmet Vakif University, İstanbul, Turkey \\ ${ }^{2}$ Faculty of Education, Erciyes University, Kayseri, Turkey \\ ${ }^{3}$ Faculty of Education, Necmettin Erbakan University, Konya, Turkey \\ Correspondence: Sahin Kesici, Faculty of Education, Necmettin Erbakan University, Konya, Turkey.
}

Received: December 26, 2016

Accepted: March 5, 2017

Online Published: March 14, 2017

doi:10.11114/jets.v5i4.2274

\author{
URL: https://doi.org/10.11114/jets.v5i4.2274
}

\begin{abstract}
The purpose of this study is to examine the relationship between teachers' psychological needs and perceived stress levels. First of all, the differentiation status of teachers' psychological needs and perceived stress levels in terms of gender, type of institution and type of the school variables was examined. Then, the psychological need's level of predicting the perceived stress was tested. This research was carried out by descriptive survey design. For this purpose, Personal Information Form, Perceived stress level scale and Psychological needs scale were applied to 498 primary school teachers (317 female $63.7 \%$ and 181 male 36.3\%). T test, $\mathrm{F}$ test and multiple linear regression analysis were applied in addition to descriptive statistics in the analysis of data. According to the results obtained from the research, it was found that the dominance needs of teachers working in private schools were significantly higher than the teachers working in public schools. It was determined that the psychological needs of teachers do not vary by gender, but the perceived stress levels of female teachers were significantly higher than male teachers. Besides, it was concluded that primary school teachers' need for relationship and secondary school teachers' need for autonomy were significantly higher compared to teachers working in other institutions. It was also determined that the needs for success, autonomy and dominance from among psychological needs significantly predicted the perceived stress. The results obtained from the research were interpreted and suggestions for further research were put forward.
\end{abstract}

Keywords: teachers, perceived stress, psychological needs, gender

\section{Introduction}

Educational institutions are the primary social institutions which are established for the realization of people's physical, cognitive, emotional and social developments in a most appropriate way to the society in which they live and to the expectations of the society. Education system has an important function that fulfills many different functions as well as the functions of transferring cultural heritage of society to new generations and socialization of the individual through institutions called school. One of the most strategic actors of the education system is undoubtedly the teachers. Because teachers have undertaken an extremely important task in terms of society such as educating today's young people as adults of the future and preparing them for ever-changing technological conditions. Besides; teachers, who have to work with people face to face and find solutions to the problems of the students or the parents as part of their job, have also many social duties such as treating everyone equally and serving as a model for their environment. School administrators, students, other teachers and parents, namely people have an important place in the working lives of teachers as part of their job. Negative situations that teachers encounter during their interaction with these people cause them to experience situations such as stress, feeling of inefficacy, anxiety and burnout by decreasing their job satisfaction. According to Cokluk (1999), although the stress in the workplace is considered as a part of daily work demands, long-term stress experienced by the individual can turn into burnout if individual cannot find opportunity to reveal himself with the work demands in question and is not supported. Indeed, it has been stated by many researchers that burnout is a condition that occurs as a result of stress (Azeem, 2010; Leiter, 2003; Maslach, 1982; Maslach \& Leiter; 1997; Surgevil, 2005; Tasgin, 2004).

The concept of stress, which was firstly defined as "the non-exclusive response of the body to any foreign demand" by Selye (1977), is also defined as the response that occurs in the event of physical and psychological stress brought about by an act or situation on the person (Hellriegel, Slocum, \& Woodman, 1992). According to Cuceloglu (2002), stress 
causes individual to exert farther effort beyond his/her physical and psychological limits due to disturbing conditions from the physical and social environment. Therefore, stress has effects of putting the person's well-being in jeopardy, reducing his/her capacity and putting him/her into trouble (Akbag, 2000; Unal \& Ummet, 2005). Although the concept of stress that has become an inseparable part of everyday life is a subject which is studies excessively in the psychology literature, there is no consensus among researchers about how to define it. The fact that the concept of stress is examined from different perspectives is the most important reason for this. Indeed, in studies carried out on stress, it is seen that stress is addressed sometimes as a stimulus, sometimes as a reaction and sometimes as a relationship under different models. According to Lazarus and Folkman (1984), stress usually describes the situations such as illness and disaster revealed by the environment and leads to a reaction in the person in the model in which stress is addressed based on a stimulus. According to model in which stress is addressed as a reaction, stress is the reaction shown by the organism as a result of the effect of the demands from the environment on the organism. Therefore, not the sources of stress but the negative situations such as anxiety, insomnia and heart throb caused by the sources of stress in the individual are evaluated.

In the third model in which stress is addressed as a process based on the relationship between the individual and the environment, the belief that whether the person shows a sign of stress will be revealed only after making an assessment comes to the forefront. According to Lazarus and Folkman (1984), among the most important advocates of this model, it is insufficient to define stress as a stimulus or reaction because stress is the interaction process between the individual and the environment. According to this model which is also defined as psychological stress, individuals show different reactions to same threats. While a person perceives stress in the same situation, another person does not perceive it. This situation reveals the importance of individual differences. According to this model, person's perception is effective in the formation of stress rather than the threats from the environment (Lazarus \& Folkman, 1984). Cuceloglu (2002), stating that some individuals are extremely nervous and stressful in a physical and social environment while some individuals are more relaxed and happy, points out that stress basically results from the person's style of evaluating and analyzing the events. Accordingly, it has been emphasized that individual's form of evaluating, directing and making sense of the events encountered by him is the main factor in decreasing and increasing the stress. Similarly, the study carried out by Lazarus et al. showed that stress does not result from the demands expected from the person, but it is related to the fact that the person evaluates whether he/she has the resources to meet those demands. This study emphasizes how important the personality traits are in the emergence of stress (Lazarus, DeLongis, Folkman, \& Gruen, 1985; Kobasa, Maddi, \& Puccetti (1982). Also, one of the important aspects of personality called as self-consciousness is important in psychological health. Ozteke, Ure and Kesici (2015) found that self-consciousness is important predictor of psychological counselors' self-efficacy.

When the literature on stress is examined, significant relationships were found between personality traits such as stress and social support perception (Chan, 2002), self-efficacy (Chan, 2003), psychological endurance (Jacelon 1997, Maddi et al., 2006; Maddi and Khoshaba, 1994), optimism or pessimism (Chang, 1996; 1998; Scheier, Weintraub, \& Carver, 1986) and collective efficacy belief (Klassen, 2010). The main reference point of these studies is focusing on the point of which psychological factors are effective for the individuals who have experienced stress but have not gave similar reactions before talking about how individuals will cope with the stress they experience. This approach is considered important in terms of providing basis for the activities to be carried out to reduce stress. Besides, carrying out further studies regarding the personal and organizational factors that will help to reduce sources of stress and weaken the negative effects of stress may enable teachers to overcome the stress in a more effective way. Therefore, the relationship between psychological needs that are thought to play a fundamental role especially in shaping of the relationships established by individuals with their environment and stress was discussed in this study.

While the concept of need is defined as the things that are necessary for the survivability of the organism and as the desire for them, it is also defined as the desire for the situations and behaviors which were experienced previously (the need for creativity and entertainment etc.) for organism to ensure and maintain the state of well-being (Matsumoto, 2009). Maslow (1970) proposes a hierarchy of needs that starts with basic biological needs and progresses towards further psychological needs that are important after basic needs are fulfilled. In the hierarchy of needs discussed by Maslow at five levels, Burger (2006) emphasizes that to meet the physiological needs is primarily necessary for the continuation of the individual's life, and time and energy can be transferred to aesthetic and intellectual interests after these basic needs are satisfied. According to Zhang (2007), there are three types of needs consisting of continuity of our lives, ensuring growth and development, and our wishes and desires emerged: physiological, psychological and social needs. While physiological needs refer to the needs arising from innate biological systems, psychological needs refer to psychological factors necessary for healthy development arising from the human nature. The needs with a psychological process consisting of emotional reactions that occur as a result of individual's interactions with other people within the socialization process are considered as social needs. 
According to the Self-Determination Theory, people have three basic psychological needs. These needs are called autonomy, efficacy and having relationship (Deci \& Ryan, 1985). According to Ryan and Deci (2008), the satisfaction of the needs of autonomy, efficacy and having relationship positively affects individuals' subjective well-being. In addition, satisfying these needs is among the main factors in order to be able to function at an optimal level. Heckert et al. (2000) defined the need for dominance as social needs in addition to the need for relationship, success and autonomy in self-regulation theory. They defined the need for success as the individual's desire to be superior and successful to move his/her previous performance forward, and they defined the need for relationship as the desire to interact socially and being accepted by others. While they defined the need for autonomy as desiring to do something for themselves rather than the others, they defined the need for dominance as the desire to be strong sometimes and to be effective on others.

In conclusion, the needs, one of the basic elements necessary for the individual's physiological, social and emotional development and for them to establish balanced relationships with the environment, and their derivatives primarily provide information about what the individual is acting towards. In addition to this, satisfying these needs adequately brings along the well-being and healthy development of the individual, as well. On the other hand, more effective social environments such as parents, teachers and administrators can be created by understanding the functions of these needs (Deci \& Ryan, 2011). Because the social environment and the society in which the people live are effective in satisfying their basic psychological needs. While the support of social environment positively affects the satisfaction of needs, non-support or questioning their decisions negatively affects the need for satisfaction. Satisfaction of the needs also determines the person's well-being level (Deci \& Ryan, 2000).

When the literature on psychological needs is examined, it is seen that there are a large number of researches to reveal the relationship between psychological needs and various variables such as internal motivation (Bell, 2010; Briand, 2009), enjoying online games (Ching \& Sunny, 2010), well-being in social groups (Sheldon \& Bettencourt, 2002), aggressiveness (Sahin \& Owen, 2009), purposes for life (İlhan \& Ozbay, 2010), decision-making strategies (Kesici, 2002), job satisfaction (Sat, Dogan and Amil, 2015), social anxiety (Kiper, 2016) and the sense of value (Bozgeyikli, 2010; Kesici, 2015). However, no study examining the relationship between psychological needs and stress perception was found. In this respect, it seems important to understand relationship between psychological needs and stress perception in individual's psychological and social development in a healthy manner. Therefore, this study focused on the relationship between teachers' stress perceptions and some psychological needs (relationship, success, autonomy and dominance). In addition, the differentiation status of teachers' psychological needs and perceived stress levels in terms of gender, type of institution and type of the school variables was also examined in the study.

\section{Method}

\subsection{Participants}

A total of 498 teachers including 317 female (63.7\%) and 181 male (36.3\%) constituted the research group. The data were collected from the research group using the following data collection tools and personal information form. Prior to application, a brief information was given to teachers about the purpose of the research and what is expected from them in this context. Then, the application was initiated.

\subsection{Instruments}

\subsubsection{Personal Information Form}

In the research, the personal information form developed by the researchers was used to determine the participants' characteristics such as gender, marital status, length of service etc.. In the personal information form, closed-end questions about the variables mentioned above were asked, and the participants were asked to mark the option appropriate for them.

\subsubsection{New Psychological Needs Scale}

Needs Assessment Questionnaire NAQ developed by Heckert et al. (2000) consists of 20 items and measures four psychological needs: Need for success, need for intimacy, need for autonomy and need for dominance. Turkish adaptation of the scale was conducted by Kesici (2008). Confirmatory factor analysis results showed that the Turkish version of the scale had a similar structure to the original four-dimensional form. The test-retest test reliabilities obtained from university students of the scale are between 0.75 and 0.85 for the four subscales. Cronbach alpha coefficients are between 0.62 and 0.77 . In this study, although the values of the "need for intimacy" subscale showed a normal distribution, it was not included in the research as the calculated internal consistency reliability was low. Examples of items: "I am a hardworking person" (success), "I like to be my own boss" (autonomy), "I try to keep the group under control when I work in a group" (dominance). 


\subsubsection{Perceived Stress Level Scale}

The Perceived Stress Scale developed by Cohen, Kamarck and Mermelstein (1983) and adapted to Turkish by Yerlikaya and İnanc (2007) is a measurement tool which is often used in different populations in the United States, Canada and Europe. PSS is a self-assessment scale developed to measure the level of stress experienced, to what extent the life of the respondent cannot be predicted and controlled, and depending on when it is evaluated as overloaded. In the scale, individuals are asked to grade how often they experienced certain emotions or thoughts within the last month between 0 (never) to 4 (very often). The stress level perceived by the respondent is determined by summing up the scores taken from the items, and high score indicates a high level of perceived stress (Cohen et al., 1983). Within the scope of the validity and reliability studies of the scale conducted in Turkey, the Turkish version was applied to a total of 246 university students consisting of 117 male and 129 female students aged between 17 and 28 ( $\mathrm{X}=20.11$; Ss= 1.51). Participants also answered the Beck Depression Inventory (BDE), which measures depressive symptoms, and the State-Trait Anxiety Inventory (STAI I and II) which measures state-trait anxiety, in addition to the Turkish version of the PSS. The average of the scores received by participants from the PSS and the standard deviation values were calculated as 27.66 and 6.96 respectively. The internal consistency alpha coefficient which was calculated to test the reliability of the scale was found as .84 . It was determined that there were positive correlations at $.65, .56, .66$ levels between PSS scores and BDE, STAI I and STAI II scores respectively. The results support that the Turkish translation of the PSS had sufficient internal consistency and criterion validity (Yerlikaya \& İnanc, 2007).

\subsection{Data Analysis}

In the research, firstly t-test was used to determine the differentiation level according to gender and type of institution variables, and one-way analysis of variance (ANOVA) test was used to determine the differentiation level according to type of the school variable. Then, Pearson correlation coefficients were calculated to determine whether there was a linear relationship between the predictive variables (Success, Relationship, Autonomy and Dominance need subscales) and the predicted variable (perceived stress). Then, the multiple linear regression analysis technique was applied to the data. In the study, the significance level was accepted as .05.

\section{Results}

T-test analysis was performed for independent groups in order to reveal the differentiation of teachers' psychological needs and perceived stress levels according to the type of the institution where they work. The findings related to the analysis performed are presented in Table 1.

Table 1. T-test results regarding the differentiation of teachers' psychological needs and perceived stress levels according to type of the institution where they work

\begin{tabular}{|c|c|c|c|c|c|c|c|}
\hline \multicolumn{2}{|c|}{ Variables } & Type of Institution & $\mathbf{N}$ & $\mathbf{x}$ & \multirow[t]{2}{*}{$\begin{array}{l}\text { Std. } \\
\text { Deviation }\end{array}$} & $\mathbf{t}$ & $\mathbf{p}$ \\
\hline \multirow{2}{*}{\multicolumn{2}{|c|}{ Success }} & Public School & 322 & 20.54 & & \multirow{2}{*}{.779} & \multirow{2}{*}{.436} \\
\hline & & Private School & 176 & 20.19 & 5.48 & & \\
\hline \multirow{6}{*}{ 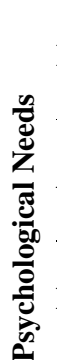 } & \multirow{2}{*}{ Relationship } & Public School & 322 & 16.12 & 2.86 & \multirow{2}{*}{.663} & \multirow{2}{*}{.508} \\
\hline & & Private School & 176 & 15.94 & 3.00 & & \\
\hline & \multirow{2}{*}{ Autonomy } & Public School & 322 & 17.55 & 4.14 & \multirow{2}{*}{.058} & \multirow{2}{*}{.953} \\
\hline & & Private School & 176 & 17.52 & 4.56 & & \\
\hline & \multirow{2}{*}{ Dominance } & Public School & 322 & 17.08 & 4.08 & \multirow{2}{*}{$-2.234 *$} & \multirow{2}{*}{.026} \\
\hline & & Private School & 176 & 17.98 & 4.62 & & \\
\hline \multirow{2}{*}{\multicolumn{2}{|c|}{ Perceived Stress }} & Public School & 322 & 23.16 & 4.48 & \multirow{2}{*}{-1.373} & \multirow{2}{*}{.170} \\
\hline & & Private School & 176 & 23.78 & 5.24 & & \\
\hline
\end{tabular}

*p $<.005$

When the findings in Table 1 are examined, it is seen that the averages of teachers working in public schools are higher than the averages of teachers working in private schools in the subscales of success, relationship and autonomy of the psychological needs scale. It is seen that the averages of teachers working in private schools are higher compared to teachers working in public schools in the subscale of need for dominance and at the perceived stress level. Both in the dimensions of psychological needs and perceived stress, when $t$ values calculated to test the significance of the difference between the groups' average scores are examined, it is seen that there is a significant difference at ,05 level 
between the groups' average scores only in the dominance subscale $(\mathrm{t}=-2.234, \mathrm{p}<.05)$. According to these findings, there is no significant difference between the teachers working in public schools and private schools in terms of the perceived stress and the needs for success, relationship and autonomy. In addition, it can be said that the dominance needs of the teachers working in private schools are higher compared to teachers working in public schools.

T-test analysis was performed for independent groups in order to reveal the differentiation of teachers' psychological needs and perceived stress levels according to gender. The findings related to the analysis performed are presented in Table 2.

When the average scores that the female and male teachers received from the sub-dimensions of the psychological needs scale are examined, it is seen in Table 2 that female teachers' average scores are high in the sub-dimension of the need for success, and male teachers' average scores are high in the sub-dimensions of relationship, autonomy and dominance. In the perceived stress dimension, it is seen that the averages of female teachers are higher than the averages of male teachers.

Table 2. T-test results regarding the differentiation of teachers' psychological needs and perceived stress levels according to their genders

\begin{tabular}{|c|c|c|c|c|c|c|c|}
\hline \multicolumn{2}{|c|}{ Variables } & \multirow{2}{*}{$\begin{array}{l}\text { Type of Institution } \\
\text { Female } \\
\text { Male } \\
\end{array}$} & \multirow{2}{*}{\begin{tabular}{l|}
$\mathbf{N}$ \\
317 \\
181 \\
\end{tabular}} & \multirow{2}{*}{$\begin{array}{l}\mathbf{X} \\
20.59 \\
20.12 \\
\end{array}$} & \multirow{2}{*}{$\begin{array}{l}\begin{array}{l}\text { Std. } \\
\text { Deviation }\end{array} \\
4.67 \\
5.20 \\
\end{array}$} & \multirow{2}{*}{$\begin{array}{l}\mathbf{t} \\
1.044\end{array}$} & \multirow{2}{*}{$\begin{array}{l}\mathbf{p} \\
.297\end{array}$} \\
\hline \multirow{5}{*}{ 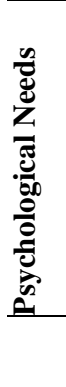 } & Success & & & & & & \\
\hline & Relationship & $\begin{array}{l}\text { Female } \\
\text { Male }\end{array}$ & $\begin{array}{l}317 \\
181 \\
\end{array}$ & $\begin{array}{l}16.06 \\
16.07 \\
\end{array}$ & $\begin{array}{l}2.90 \\
2.92 \\
\end{array}$ & -.035 & .972 \\
\hline & Autonomy & $\begin{array}{l}\text { Female } \\
\text { Male }\end{array}$ & $\begin{array}{l}317 \\
181 \\
\end{array}$ & $\begin{array}{l}17.50 \\
17.61 \\
\end{array}$ & $\begin{array}{l}4.18 \\
4.48 \\
\end{array}$ & -.273 & .785 \\
\hline & Dominance & $\begin{array}{l}\text { Female } \\
\text { Male }\end{array}$ & $\begin{array}{l}317 \\
181\end{array}$ & $\begin{array}{l}17.35 \\
17.48\end{array}$ & $\begin{array}{l}4.08 \\
4.66\end{array}$ & -.326 & .745 \\
\hline & Perceived Stress & $\begin{array}{l}\text { Female } \\
\text { Male }\end{array}$ & $\begin{array}{l}317 \\
181\end{array}$ & $\begin{array}{l}23.81 \\
22.62\end{array}$ & $\begin{array}{l}4.51 \\
5.11\end{array}$ & $2.692 *$ & .007 \\
\hline
\end{tabular}

*p<.005

When $t$ values calculated to test the significance of the difference between the groups' average scores are examined, it was determined that there was no significant difference between the groups in four sub-dimensions of the psychological needs. In addition, $t$ value calculated for the perceived stress $(t=2.692, \mathrm{p}<.05)$ indicates that the difference between the groups' average scores is significant at .05 level. According to this finding, it can be said that female teachers' perceived stress levels are significantly higher compared to male teachers.

Independent one-way analysis of variance (ANOVA) was performed in order to reveal the differentiation of teachers' psychological needs and perceived stress levels according to type of the school where they work. The findings related to the analysis performed are presented in Table 3.

Table 3. Anova (F test) results regarding the differentiation of teachers' psychological needs and perceived stress levels according to type of the school where they work

\begin{tabular}{|c|c|c|c|c|c|c|c|}
\hline \multicolumn{2}{|c|}{ Variables } & \multirow{2}{*}{$\begin{array}{l}\text { Type of the school } \\
\text { Primary school }\end{array}$} & \multirow{2}{*}{$\begin{array}{l}\mathbf{N} \\
146\end{array}$} & \multirow{2}{*}{$\begin{array}{l}\mathbf{X} \\
19.85\end{array}$} & \multirow{2}{*}{$\begin{array}{l}\text { Std. } \\
\text { Deviation } \\
5.44\end{array}$} & \multirow[t]{2}{*}{$\mathbf{F}$} & \multirow[t]{2}{*}{$\mathbf{p}$} \\
\hline & & & & & & & \\
\hline \multirow{14}{*}{ 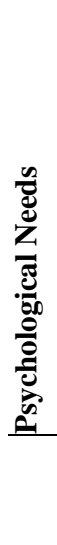 } & Success & Secondary school & 194 & 20.63 & 4.32 & 1.413 & .244 \\
\hline & & High school & 158 & 20.68 & 4.93 & & \\
\hline & & Primary school & 146 & 15.54 & 3.00 & & \\
\hline & Relationship & Secondary school & 194 & 16.04 & 2.90 & 4.813* & .009 \\
\hline & & High school & 158 & 16.57 & 2.75 & & \\
\hline & & Primary school & 146 & 17.49 & 4.51 & & \\
\hline & Autonomy & Secondary school & 194 & 18.20 & 3.83 & 4.877* & .008 \\
\hline & & High school & 158 & 16.77 & 4.50 & & \\
\hline & & Primary school & 146 & 17.14 & 4.81 & & \\
\hline & Dominance & Secondary school & 194 & 17.49 & 3.89 & .360 & .698 \\
\hline & & High school & 158 & 17.51 & 4.28 & & \\
\hline & & Primary school & 146 & 23.14 & 4.83 & & \\
\hline & Perceived Stress & Secondary school & 194 & 23.81 & 4.47 & 1.283 & .278 \\
\hline & & High school & 158 & 23.08 & 5.05 & & \\
\hline
\end{tabular}


When the findings in Table 3 are examined, it is seen that the teachers working in high schools have the highest average in the success, relationship and dominance sub-dimensions of the psychological needs scale, and the teachers working in secondary schools have the highest average in the autonomy sub-dimension. It is observed that while the teachers working in secondary schools have the highest average in the perceived stress dimension, the teachers working in high schools have the lowest average in this dimension. When $\mathrm{F}$ values calculated to test the significance of the difference between the groups' average scores are examined, it is seen that there is a significant difference at .05 level only in the sub-dimensions of relationship and autonomy needs. The TUKEY test was applied as a further analysis to find the source of the difference between the averages of the groups, and the findings obtained are presented in Table 4.

Table 4. Turkey test results regarding the differentiation of teachers' needs for relationship and autonomy according to type of the institution where they work

\begin{tabular}{lllll}
\hline \multirow{2}{*}{ Dependent Variable } & (I) Type of Institution & (J) Type of Institution & \multicolumn{2}{c}{ Difference Between Averages } \\
\hline \multirow{2}{*}{ Relationship } & Primary school & Secondary school & -.495 & p \\
& & High school & -1.029 & .263 \\
& Secondary school & High school & -.534 & .006 \\
\hline \multirow{2}{*}{ Autonomy } & Primary school & Secondary school & -.703 & .198 \\
& & High school & .721 & .289 \\
& Secondary school & High school & 1.424 & .304 \\
\hline
\end{tabular}

$* \mathrm{p}<.005$

When Table 4 is examined, it is seen that the difference in the relationship sub-dimension of the psychological needs is in favor of high school teachers between the teachers working in primary schools and the teachers working in high school. According to this finding, the teachers working in high schools exhibit further need for relationship compared to teachers working in primary schools. When findings regarding the source of the difference in the sub-dimension of the need for autonomy is examined, it is understood from Table 4 that the difference emerged is in favor of the teachers working in secondary schools. According to this finding, it can be said that the autonomy needs of the teachers working in secondary schools are significantly higher compared to teachers working both in primary and high schools.

The scores that teachers received from the sub-dimensions of the psychological needs scale and the Pearson Correlation analysis results applied to these scores to determine the relationship between the total score of perceived stress are presented in Table 5

Table 5. Pearson's correlation values regarding the relationship between teachers' psychological needs and perceived stress levels

\begin{tabular}{llllll}
\hline & & Success & Relationship & Autonomy & Dominance \\
\hline \multirow{3}{*}{ Perceived Stress } & $\mathrm{r}$ & $.440^{* * *}$ & $.224^{* * *}$ & $.502^{* * *}$ & $.444^{* * *}$ \\
& $\mathrm{p}$ & .000 & .000 & .000 & .000 \\
& $\mathrm{~N}$ & 498 & 498 & 498 & 498 \\
\hline
\end{tabular}

When the correlation values in Table 5 are examined, it is seen that there is a positive significant correlation between the success, relationship, autonomy and dominance sub-dimensions of the psychological needs scale and the perceived stress. According to this finding, it can be said that the level of perceived stress also increases as the psychological needs increase.

Multiple linear regression analysis was performed to determine the strength of the sub-dimensions of the teachers' psychological needs scale to predict the perceived stress level, and the findings related to analysis performed are presented in Table 6.

Table 6. Multiple regression analysis results regarding the predicting of the perceived stress level by psychological needs

\begin{tabular}{llllll}
\hline $\begin{array}{l}\text { Predictive } \\
\text { Variables }\end{array}$ & $\mathbf{B}$ & Std. Error & $\mathbf{B}$ & $\mathbf{t}$ & $\mathbf{p}$ \\
\hline Constant & 9.716 & 1.179 & & 8.241 & .000 \\
Success & .120 & .053 & .123 & $2.273^{*}$ & .023 \\
Relationship & .121 & .072 & .074 & 1.681 & .093 \\
Autonomy & .374 & .058 & .336 & $6.435^{*}$ & .000 \\
Dominance & .156 & .059 & .141 & $2.644^{*}$ & .008 \\
\hline $\mathrm{R}=.549$ & $\mathrm{R}^{2}=.302$ & \multicolumn{2}{c}{$\mathrm{F}_{(4-493)=} 53.242$} & $\mathrm{P}=.001$ & \\
\hline
\end{tabular}

According to findings in Table 6, R2 value which is the degree of explaining the teachers' perceived stress levels with psychological needs was calculated as .302. According to this finding, it was found that all analyzed sub-dimensions of the psychological needs explained the teachers' perceived stress levels at .05 significance level by $30.2 \%$. When the 
t-test results for the independent variables are examined, it is seen that three variables of four independent variables analyzed (need for success $(\beta=.123)$, need for autonomy $(\beta=.336)$ and need for dominance $(\beta=.141)$ ) positively predicted the perceived stress at, 05 level. While the need for autonomy is the strongest predictor of the perceived stress among these three variables, it is followed by the needs for dominance and success. Besides, the level of the need for relationship to predict the perceived stress by itself was not found significant at .05 level.

\section{Discussion}

In this study, which was carried out on teachers and focused on the relationship between the perceived stress level and psychological needs, the differentiation status in terms of gender, type of institution and type of the school variables was firstly examined. According to the results obtained in terms of the institution type variable, while no significant difference was found between the teachers working in private and public schools in terms of the perceived stress and the needs for success, relationship and autonomy, and that the needs for the dominance of teachers working in private schools were higher compared to teachers working in public schools. When the literature on psychological needs was examined, a study in which working in public and private institutions is directly examined as a variable was not determined. In addition to this, the fact that the dominance needs, meaning to influence, control and manage the others and to influence the tendency of a group, of teachers working in private schools was higher than the dominance needs of teachers working in the public in this research can be explained by the structure of the institution where they work. Namely, teachers working in private schools also have to fulfill the specific tasks arising from the special conditions of the school in addition to duties and responsibilities such as courses, seizures, educational studies and project studies given to them by the regulations (Bozgeyikli \& Sat, 2014). This situation naturally leads to a working environment that requires them to be more dominant, hence it can be said that the dominance needs of teachers working in private institutions are increasing.

The fact that there is not a significant difference between teachers working in public and private institutions in terms of the perceived stress level is also quite noteworthy. Indeed, the fact that private schools create more stress on their employees in terms of working conditions is an expected climate. However, the fact that there is no significant difference in terms of the perceived stress can be explained based on the basic ideas of the transactional model in which stress is addressed as a process based on the relationship between the individual and the environment. According to transactional model, person's perception is effective in the formation of the stress rather than the threats from the environment (Lazarus and Folkman, 1984). When it is viewed from this aspect, these situations, that can be considered significant stress factors for teachers in public institutions as they exist there with a preliminary acceptance regarding the climate created by the institutions for which they work, do not have the same effect for the individual working in private institutions.

According to the obtained results regarding the differentiation of teachers' psychological needs and perceived stress levels according to gender, no significant difference was determined at the level of psychological needs of male and female teachers. Besides, it was determined that female teachers' perceived stress levels were higher compared to their male colleagues. When the literature regarding the differentiation of psychological needs according to gender is examined, it is seen that different results appeared in different sample groups. For instance, while differences according to gender were determined in some sub-dimensions in the studies investigating the psychological needs of prospective teachers, it was determined in the study which was carried out by Genctanırım and Tay (2015) with prospective classroom teachers that psychological needs did not differ according to gender. In the study carried out on academicians by Sat, Amil and Dogan (2015), it was concluded that female academics' need for success was higher compared their male colleagues. In the study carried out by Bozgeyikli, Sunbul, Kesici and Ure (2003) on primary school teachers, it was found that female teachers' need levels were higher only in the dimension of the need for efficacy compared to male teachers. When the findings related to gender obtained in this study are compared with the findings in the related literature, it is concluded that psychological needs differ by individuals' social roles and positions rather than gender. The result that the female teachers' perceived stress levels are significantly higher compared to male teachers in the perceived stress level is consistent with the findings of various researches in the literature (Eskin, Harlak, Demirkıran and Dereboy, 2013; Hamad, Ferland, Karlan and Zinman, 2008; Savc1 \& Aysan, 2014). Garnefski et al. (2004) explained the fact that female teachers' perceived stress levels are higher than males' with various opinions in their study carried out on depression and gender. According to them, the depression difference between females and males may emerge as a result of the difference related to issues of socio-economic status, educational level, acceptance of being depressive, and a request for help to get rid of depression between them. Besides, the fact that females are hormonally and genetically more open to depression and that they are more exposed to negative life events may also cause this situation. In addition, the fact that women are further exposed to depression than men may result from the fact that they mostly resort to passive and emotion focused dealing ways in stress and distress situations. It can be said that it is important to show approaches based on reduction of stress factors in working environments in order to reduce the stress 
level perceived by working women based on both the findings in the literature and these opinions.

When the results revealed in terms of the variable of the type of school where they work, which is another variable discussed in the research, are examined, it was determined that there was a significant difference only in the dimensions of the need for relationship and autonomy, and no significant difference was observed in terms of the perceived stress and the need for success and dominance. While it was determined in the dimension of the need for relationship that the level of needs of teachers working in high schools were significantly higher compared to their colleagues working in primary school, it was determined in the dimension of the need for autonomy that the autonomy needs of teachers working in secondary schools were higher compared to their colleagues working in both primary and high schools. When the literature on psychological needs was examined, no study in which the type of institution where they work is examined as a variable was found. However, the fact that high school teachers' need for relationship and the need for autonomy of teachers working in secondary schools are high verifies the fact that psychological needs are not independent of the social environment and relationships (Sheldon, Elliot, Kim, \& Kasser, 2001). The difference in the nature of interpersonal relationships that allow or prevent the satisfaction of basic psychological needs may also be the cause of the difference that emerges in the psychological needs of teachers working in different institutions. Indeed, the findings regarding the fact that basic psychological needs vary by high schools which were in the study carried out on high school students by Celikkaleli, Gokcakan and Capri (2005), and also Bayraktar's (2011) study findings regarding the fact that the variable of social environment (village, district, province) affects the need for autonomy are consistent with the findings obtained in this study in terms of the nature of the social environment and relationships.

When the results revealing the relationship between perceived stress and psychological needs, that constitute the primary purpose of the research, are examined, it is seen that there is a positive significant relationship between the success, relationship, autonomy and dominance sub-dimensions of the psychological needs scale and the perceived stress. In addition, whether psychological needs are a significant predictor of the perceived stress was examined, and it was determined that the needs for autonomy, dominance and success explained the perceived stress by $30 \%$. According to this finding, it can be said that the fact that the psychological needs of teachers are not adequately met may cause them to perceive more stress in their lives. These findings are consistent with the main ideas of self-determination theory.

As a result of the satisfaction of the psychological needs, positive self-perception of the individual and individual's well-being status increase (Ryan \& Deci, 2000). The needs for success, relationship, autonomy and dominance are the basic needs which are required to meet the other psychological and social needs of the individual. The need for autonomy that emerged as the strongest predictor of the perceived stress in research is one of the most important needs for competence and individualization (Cripps \& Zyromski, 2009). Satisfying the need for autonomy, which is a need based on individual's power to reveal himself/herself, allows individual to be more relaxed and less stressful. Teachers are in a social interaction with the students and the parents in the working environments by the nature of the teaching profession. Failure to satisfy the dominance needs, meaning to influence, control and manage the others and to influence the tendency of a group in this interaction process, naturally leads them to have more stress. On the other hand, the need for the success of the psychological needs is one of the basic psychological needs that affect the individual in many respects compared to others and that positively affect the other needs and actions by satisfaction. Personal and social areas that prepare individual to feel himself/herself good free from stress primarily regard the fulfillment of basic primary needs such as success and competence as necessary (Ryan \& Deci, 2000; Burger, 2006). Deveci (2007) states that individuals who meet the needs for success, autonomy and relationship feel more relaxed and peaceful. Also Ozteke Kozan (2016) stated that psychological counselors need to create the emphathetic environment and state similar experiences in reducing stress among families with disabled children.

Consequently, different personality traits of individuals naturally affect the degree of being affected by the stress. When it is considered that personality traits are different in teachers, the degree of being affected by stress will be different. However, the stress experienced by teachers should be evaluated differently from the stress experienced by other people and the consequences caused by it. Because the stress that teachers will experience during the education and training process performed with students in a social environment may cause them to give more negative reactions to their surroundings. This also negatively affects the learning environment. Therefore, teachers should be free from stress and relaxed to perform effective communication with their students. In sum, the role and attitude of teachers are important for students (Buyukkaragoz \& Kesici, 1998). The improvement of democratic beliefs of teachers (Buyukkaragoz, Kesici, \& Yyilmaz, 1995) and psychological needs of students (Kesici, 2007) are also important factors in education. Thus, the educational programs also need be prepared by considered the psychological needs of teachers. 


\section{References}

Akbag, M. (2000). The Investigation of coping with stress attitutes in terms of negative automatic thoughts, ego states and some variables among university students. (Unpublished doctoral thesis). Marmara University, Turkey

Azeem, S. M. (2010). Personality hardiness, job involvement and job burnout among teachers. International Journal of Vocational and Technical Education, 2(3), 36-40.

Bayraktar, G. (2011). The investigation of basic psychological needs and depression levels of wrestlers in terms of some variables, SPORMETRE Physical Education and Sports Science Journal, 9(1), 15-23.

Bell, G. N. (2010). Self Determination Theory and Therapeutic Recreation: The Relevance of autonomy, Competence and Relatedness to Participant Instrinsic Motivation, Degree of Philosophy, Clemson University.

Bozgeyikli, H. (2010). The relationship between high school students' psychological needs and human value perceptions. Procedia Social and Behavioral Sciences, 9, 1798-1804. https://doi.org/10.1016/j.sbspro.2010.12.403

Bozgeyikli, H., \& Sat, A. (2014). The investigation of psychological resilience and organizational citizenship in terms of some variables. HAK-IS International Labor and Society Journal, 3(5), 172-191.

Bozgeyikli, H., Sunbul, A. M., Kesici, S., \& Ure, O. (2003). Ilkogretim ogretmenlerinin, ogrencileri motive etme duzeyleri ile temel psikolojik ihtiyaclarının iliskisel analizi. VII. Ulusal Psikolojik Danısma ve Rehberlik Kongresi. Malatya: Inonu Universitesi.

Briand, M. (2009). The Relationship Between Authentic Leadership, Psychological Needs Satisfaction and Motivation. Concordia University Press.

Burger, J. M. (2006). Personality. Istanbul: Kaknus Publishing.

Buyukkaragoz, S. S., \& Kesici, S. (1998). The role of teachers and the effect of their attitudes on students' behaviors in education. National Education Journal, 137, 68-73.

Buyukkaragoz, S. S., Kesici, S., \& Y1lmaz, A. (1995). Higher Education programmes and democratic attitudes, Selcuk University Journal of Educational Faculty.

Celikkaleli, O., Gokcakan, N., \& Capri, B. (2005). The investigation of psychological needs of high school students in terms of gender, school type and family education level. Uludag University Journal of Educational Faculty, 18(2), 245-268.

Cetin, M. C., Gezer, E., Yıldız, O., \& Y1ldı, M. (2013). Investigation of the relationship between aggression levels and basic psychological needs school of physical education and sports students. International Journal of Human Sciences, 10(1), 1738-1753.

Chan, D. W. (2002). Stress, self-efficacy, social support, psychological distress among prospective Chinese teachers in Hong Kong. Educational Research Journal, 22(5), 557-669. https://doi.org/10.1080/0144341022000023635

Chan, D. W. (2003). Hardiness and its role in the stress-burnout relationship among prospective Chinese teachers in Hong Kong. Teaching and Teacher Education, 19(4), 381-395. https://doi.org/10.1016/S0742-051X(03)00023-4

Chang, E. C. (1996). Cultural differences in optimism, pessimism, and coping: Predictors of subsequent adjustment in Asian American and Caucasian American college students. Journal of Counseling Psychology, 43(1), 113-123. https://doi.org/10.1037/0022-0167.43.1.113

Chang, E. C. (1998). Dispositional optimism and primary and secondary appraisal of a stressor: Controlling for confounding influences and relations to coping and psychological and physical adjustment. Journal of Personality and Social Psychology, 74(4), 1109-1120. https://doi.org/10.1037/0022-3514.74.4.1109

Chiang Y. T., \& Sunny S. S. J. L. (2010). Early adolescent players' playfulness and psychological needs in online games. Social Behavior and Personality, 38(5), 627-636. https://doi.org/10.2224/sbp.2010.38.5.627

Cohen, S., Kamarck, T., \& Mermelstein, R. (1983). A global measure of perceived stress. Journal of Health and Social Behavior, 24(4), 385-396. https://doi.org/10.2307/2136404

Cokluk, O. (1999). Exhaustion of managers and teachers working in mental and hearing impairment schools (Unpublished master thesis). Ankara University, Ankara.

Cripps, K.., \& Zyromski, B. (2009). Adolescents' psychological well-being and perceived parental involvement: Implications for parental involvement in middle schools. Research in Middle Level Education Online, 33(4), 1-13. https://doi.org/10.1080/19404476.2009.11462067

Cuceloglu, D. (2002). Human and Behavior. İstanbul: Remzi Publishing 
Deci, E. L., \& Ryan, R. M. (1985). Intrinsic motivation and self-determination in human behavior. NY: Plenum Press. https://doi.org/10.1007/978-1-4899-2271-7

Deci, E. L., \& Ryan, R. M. (2000). The 'what' and 'why' of goal pursuits: Human needs and the self-determination of behavior, Psychological Inquiry, 1, 227-268. https://doi.org/10.1207/S15327965PLI1104_01

Deci, E. L., \& Ryan, R. M. (2011). Levels of analysis, regnant causes of behavior, and well-being: The role of psychological needs. Psychological Inquiry, 22, 17-22. https://doi.org/10.1080/1047840X.2011.545978

Deveci, H. (2007). The views of teachers regarding psychological needs. (Unpublished master thesis). Selcuk University, Konya.

Eskin, M., Harlak, H., Demirkıran, F., \& Dereboy, C. (2013). The adaptation of perceived stress scale into Turkish: Validity and Reliability Analysis. New/Yeni Semposium Journal, 51(3), 132-140.

Garnefski, N., Teerds, J., Kraaij, V., Legerstee, J., \& van den Kommer, T. (2004). Cognitive emotion regulation strategies and depressive symptoms: Differences between males and females. Personality and Individual Differences, 36(2), 267-276. https://doi.org/10.1016/S0191-8869(03)00083-7

Genctanırım, D., \& Tay, B. (2015). The psychological needs of candidate of primary school teachers. Elementary Education Online, 14(2), 647-656.

Gundogdu, R., \& Yavuzer, Y. (2012). The investigation og subjective well being and psychological needs of Educational Faculty students in terms of demographic variables. Mehmet Akif Ersoy University Journal of Educational Faculty, $23,115-131$.

Hamad, R., Fernald, L., Karlan, D., \& Zinman, J. (2008). Social and economic correlates of depressive symptoms and perceived stres in South African Adults. Journal of Epidemiology and Community Health, 62, 538-544. https://doi.org/10.1136/jech.2007.066191

Heckert, T. M., Cuneio, G.., Hannah, A. P., Adams, P. J., Droste, H. E., \& Mueller, M. A. (2000). Creation of a new needs assessment questionnarre. Journal of Social Behavior Personality, 15(1), 121-136.

Hellriegel, D., Slocum, J. W., Jr., \& Woodman, R. W. (1992). Organizational behavior. Encyclopedia of Human Behavior. https://doi.org/10.1016/B978-0-12-375000-6.00263-9

Ilhan, T., \& Ozbay, Y. (2010). The role of life aims and psychological needs on psychological well being. Turkish Psychological Counseling Journal, 33, 109-119

Jacelon, C. S. (1997). The trait and process of resilience. Journal of Advanced Nursing, 25(1), 123-129. https://doi.org/10.1046/j.1365-2648.1997.1997025123.x

Kesici, S. (2002). Th investigation of decision making of university students in terms of psychological needs and some variables (Unpublished Doctoral Thesis). Selcuk University, Konya.

Kesici, S. (2007). Psychological needs of 6-7-8- grade students according to views of school counselors. Selcuk University Social Science Institute Journal, 17, 365-383.

Kesici, S. (2008). New Psychological Needs Questionnaire: Confirmatory Factor Analysis Results. Selcuk University Social Science Institute Journal, 20, 493-500.

Kesici, S. (2015). Psychological needs as predictors of human values in high school students, The Anthropologist, 19(2), 499-506.

Kiper, Y. C. (2016). The prediction of perfectionism levels of university students by social anxiety and psychological needs. OPUS - International Society Research Journal, 6(10), 127-155.

Klassen, R. M. (2010). Teacher stress: The mediating role of collective efficacy beliefs. The Journal of Educational Research, 103(5), 342-350. https://doi.org/10.1080/00220670903383069

Kobasa, S.C., Maddi, S.R., \& Puccetti, M.C. (1982). Personality and exercise as buffers in the stress-illness relationship. Journal of Behavioral Medicine, 5(4), 391-404. https://doi.org/10.1007/BF00845369

Lazarus, R. S., \& Folkman, S. (1984). The stress concept in the life sciences. Stress, Appraisal, and Coping, 1-21.

Lazarus, R., DeLongis, A., Folkman, S., \& Gruen, R. (1985). Stress and adaptational outcomes: The problem of confounded measures. American Psychologist, (7), 770-779. https://doi.org/10.1037/0003-066X.40.7.770

Leiter, M.P. (2003). Areas of worklife survey manual (4th edition), Center for organizational research and development. Wolfville, NS: Center for Organizational Research and Development.

Maddi, S. R., \& Khoshaba, D. M. (1994). Hardiness and mental Health. Journal of Personality Assessment, 63(2), 


\section{5-274. https://doi.org/10.1207/s15327752jpa6302_6}

Maddi, S. R., Harvey, R. H., Khoshaba, D. M., Lu, J. L., Persico, M., \& Brow, M. (2006). The personality construct of hardiness, III: Relationships with repression, innovativeness, authoritarianism, and performance. Journal of Personality. https://doi.org/10.1111/j.1467-6494.2006.00385.x

Maslach, C. (1982). Burnout: The cost of caring. Englewood Cliffs, NJ: PrenticeHall.

Maslach, C., \& Leiter, M. P. (1997). The truth about burnout. San Francisco, CA: Jossey-Bass.

Maslow, A. (1970). A Theory of human motivation. Psychological Review, 50, 370-396. https://doi.org/10.1037/h0054346

Matsumoto, D. (2009). The cambridge dictionary of psychology. UK: Cambridge University Press.

Ozteke, H. I., Ure, O., \& Kesici, S. (2015). The prediction of elementary school counselors' self-efficacy beliefs by social comparison and self-consciousness. Online Journal of Counseling \& Education, 4(1), 34-45.

Ozteke-Kozan, H. I. (2016). Psychological counselor tasks and skills in coping stress working with families with disabled children. Paper presented in I. International Academic Research Congress, Antalya, Turkey.

Ryan, R. M., \& Deci, E. L. (2000). The darker and brighter sides of human existence: Basic psychological needs as a unifying concept. Psychological Inquiry, 11(4), 319-338. https://doi.org/10.1207/S15327965PLI1104_03

Ryan, R. M., \& Deci, E. L. (2008). Self-determination theory and the role of basic psychological needs in personality and the organization of behavior. John et al. (eds.) Handbook of Personality: Theory and Research, NY: The Guilford Press.

Sahin, E. S., \& Owen, F. K. (2009). The aggresiveness levels of high school students with different psychological needs. Turkish Psychological Counseling Journal, 32, 64-74.

Sat, A., Dogan, H., \& Amil, O. (2015). The investigation of psychological needs and work satisfaction of academicians in terms of some variables. OPUS -Turkish Social Politics and Work Life Research Journal, 5(8), 112-132.

Savc1, M., \& Aysan, F. (2014). The relationship between perceived stress level and coping strategies in university students. International Turkish Educational Sciences Journal, 3, 44-56.

Scheier, M. F., Weintraub, J. K., \& Carver, C. S. (1986). Coping with stress: divergent strategies of optimists and pessimists. Journal of Personality and Social Psychology, 51(6), 1257-1264. https://doi.org/10.1037/0022-3514.51.6.1257

Selye, H. (1946). The general adaptation syndrome and the diseases of adaptation. Journal of Clinical Endocrinology, 6, 117-231. https://doi.org/10.1210/jcem-6-2-117

Sheldon, K. M., \& Bettencourt, B. A. (2002). Psychological need satisfaction and subjective Well-being within social groups. British Journal of Social Psychology, 41, 25-38. https://doi.org/10.1348/014466602165036

Sheldon, K. M., Elliot, A. J., Kim, Y., \& Kasser, T. (2001). What is satisfying about satisfying events? Testing 10 candidate psychological needs. Journal of Personality and Social Psychology, 80, 325-339. https://doi.org/10.1037/0022-3514.80.2.325

Surgevil, O. (2005). Burnout and factors effect it: An application on academic staff. (Unpublished master thesis) Dokuz Eylul University, Izmir.

Tasgın, O. (2004). Genclik ve spor genel mudurlugu merkez ve tasra orgutu yoneticilerinin tukenmislik duzeylerinin is doyum duzeylerine etkisi (Yayınlanmamıs Doktora Tezi). Selcuk Universitesi, Sosyal Bilimler Enstitusu, Konya.

Unal, S., \& Ummet, D. (2005). Organizational stress resources and coping stragies of teachers. National Educational Science Conference. Denizli, Pamukkale University

Yerlikaya, E. E., \& İnanc, B. (2007). The Turkish Perceived stress scale: Psychometric properties. IX. National Psychological Counseling Congress, 17-19 October, Izmir, Turkey.

Zhang, P. (2007). Toward a positive design theory: Principles for designing motivating information and communication technology. Advances in Appreciative Inquiry. https://doi.org/10.1016/S1475-9152(07)00204-9

\section{Copyrights}

Copyright for this article is retained by the author(s), with first publication rights granted to the journal.

This is an open-access article distributed under the terms and conditions of the Creative Commons Attribution license which permits unrestricted use, distribution, and reproduction in any medium, provided the original work is properly cited. 